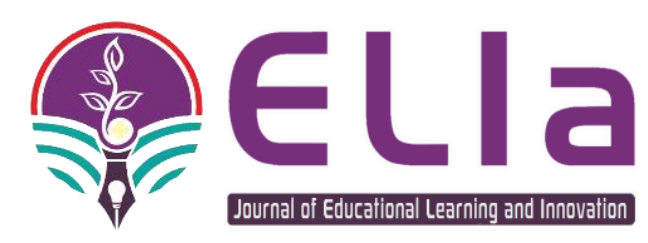

Journal of

Educational Learning and Innovation

p-ISSN:2775-2623 and e-ISSN: 2775-2739

Volume 1 Number 1 Maret 2021, Halaman 15-23

DOI: 10.46229/elia.v1i1

\title{
STUDI ANALISIS PERSIAPAN ORANG TUA SELAMA PEMBELAJARAN DARING KELAS I SDN 01 KAJEKSAN KUDUS
}

\author{
Dina Sakhiratul Rizki ${ }^{1}$, Elya Umi Hanik ${ }^{2}$ \\ ${ }^{1}$ Institut Agama Islam Negeri Kudus, Kudus, Indonesia \\ Email: dinasakhira@gmail.com \\ ${ }^{2}$ Institut Agama Islam Negeri Kudus, Kudus, Indonesia \\ Email: elyaumi@iainkudus.ac.id
}

(Received: 28 Desember- 2020; Reviewed: 09 Januari-2021; Accepted: 04 Februari-2021;

Available online: Maret-2021; Published: Maret-2021)

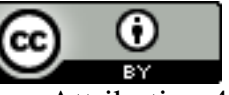

This is an open access article distributed under the Creative Commons

Attribution License

Attribution 4.0 International (CC BY 4.0) (https://creativecommons.org/licenses/by-nc/4.0/ ).

\author{
ARTIKEL INFO \\ Kata Kunci: \\ Pandemi covid-19; \\ Pembelajaran \\ Daring; Belajar \\ Dari Rumah.
}

\begin{abstract}
Abstrak. Saat ini dengan adanya pandemi pemerintah memutuskan untuk mengadakan program belajar dari rumah agar penyebaran pandemi di Indonesia tidak terus menyebar dan juga dengan adanya kegiatan tersebut membuat orang tua untuk bisa ikut memberi arahan anak dalam belajar di rumah proses ini memang cukup sulit dan pasti akan banyak menemui tantangan. Kegiatan ini dilakukan untuk mengetahui gambaran mengenai kesiapan dari orang tua terhadap adanya pembelajaran daring karena adanya covid 19. Metode penelitian yang penulis pilih adalah metode kualitatif deskriptif dengan cara melakukan observasi serta wawancara. Dari hasil penelitian sendiri menunjukan bahwa perlu adanya persiapan orang tua dalam proses pembelajaran seseorang mulai dari kondisi, fisik, dan mental seseorang yang mampu untuk melaksanakan sebuah kegiatan pembelajaran. Adapun peran orang tua selama pembelajaran daring sangat diperlukan karena orang tua sebagai pendidik utama dan pertama serta berkelanjutan bagi anak-anak mereka. Dan juga masih ada beberapa kendala yang dihadapi orang tua di dalam mendampingi anak belajar secara daring. Diantaranya permasalahan pada kesulitan di dalam menjelaskan materi atau tugas kepada murid serta keterbatasan waktu yang dipunyai dalam mendampingi anak belajar. Serta kadang orang tua yang tidak mengetahui jika ada tugas yang sudah di kirim oleh guru di karenakan orang tua tidak selalu memegang handphone.
\end{abstract}

\begin{abstract}
Currently with the pandemic the government has decided to hold a home learning program so that the spread of the pandemic in Indonesia does not continue to spread and also with these activities, parents must be able to accompany their children to learn from home, this is certainly not easy to do because it is certain in these activities There are so many obstacles that must be passed. This research was conducted in order to find an overview of the readiness of parents for online learning due to the presence of covid 19. The research method that the writer chose was descriptive qualitative method by observing and conducting interviews. From the results of the research itself shows that it is necessary to prepare parents in the learning process of a person starting from the condition, physical and mental condition of a person
\end{abstract}


who is able to carry out a learning activity. As for the role of parents during online learning is very necessary because parents are the primary and first and continuing educators for their children. And there are still some obstacles that parents face in assisting their children to learn online. Among them are the problems with the difficulty in explaining the material or assignments to students and the limited time they have in accompanying children to learn. And sometimes parents don't know if there is an assignment that has been sent by the teacher because parents don't always have a cellphone.

\section{PENDAHULUAN}

Orang tua yaitu pendidik awal dan paling penting bagi anak mereka karena keluarga adalah awal dari anak mendapat pendidikan. Oleh karena itu sumber pertama pendidikan terdapat dalam keluarga. Orang tua adalah tempat dimana anak bisa mendapat tempat bersandar serta harapan. Mereka berdualah awal tempat dimana seorang anak bisa merasakan kasih sayang serta kelembutan dan penjagaan serta pemeliharaan. Orang tua akan dianggap oleh anak sebagai tempat bagi mereka mengadu mengenai semua masalah yang sedang mereka hadapi.

Pada tahun ini negara kita sedang mendapat musibah, yaitu tersebarnya wabah yang melanda seluruh dunia yang disebut virus covid 19. Hadirnya virus ini menjadihkan semua aktivitas belajar mengajar dilakukan dari rumah, hal ini dilakukan untuk menjaga kesehatan serta untuk menciptakan rasa aman bagi kita semua. Keadaan ini tentunya sangat berpengaruh pada kehidupan orang tua, dalam kondisi seperti ini orang tua diharapkan untuk bisa ikut berpertisipasi di dalam memberikan pendampingan belajar untuk anak selama belajar dirumah.

Dikarenakan besarnya peran orang tua dalam mendidik anak, sudah banyak penelitian yang sudah membuktikan jika orang tua sangat memiliki kontribusi yang penting di dalam meningkatkan kemampuan anak di dalam pendidikan.
Penelitian yang sudah membahas topik tersebut antara lain penelitian yang sudah dilakukan oleh Valeza (2017) Untuk penelitian ini mengungkapkan jika peran orang tua di dalam memaksimalkan prestasi belajar anak sungguh berpengaruh. Orang tua yang berhasil memberikan perhatian pada proses pembelajaran anak dirumah, maka akan menyebabkan anak menjadi bersemangat dalam belajar. Oleh karena itu, peran orang tua sangat dibutuhkan sebagai pengganti guru dirumah selama pembelajaran daring pada saat ini.

Peran orang tua sangat diperlukan untuk memberikan pendidikan terhadap anak nya. Orang tua juga sebagai pendidik utama dan pertama serta berkelanjutan untuk anak-anaknya apalagi di dalam kondisi pandemi saat ini, maka dengan semua penjelasan diatas peneliti menyatakan bahwa perlu adanya persiapan orang tua dalam proses pembelajaran seseorang mulai dari kondisi, fisik, dan mental seseorang yang mampu untuk melaksanakan sebuah kegiatan pembelajaran. Adapun peran Orang tua dalam pembelajaran daring ini sangatlah penting guna membantu keterlibatan dari Orang tua agar lebih efektif. Dan juga masih ada beberapa kendala yang dihadapi orang tua di dalam mendampingi anak belajar secara daring. Diantaranya permasalahan pada kesulitan di dalam menjelaskan materi atau tugas kepada murid serta keterbatasan waktu yang 
dipunyai dalam mendampingi anak belajar. Serta kadang orang tua yang tidak mengetahui jika ada tugas yang sudah di kirim oleh guru di karenakan orang tua tidak selalu memegang handphone.

\section{METODE}

Pada penelitian kali ini peneliti memilih menggunakan metode penelitian deskripsi kualitatif. Menurut pendapat Sukmadinata (2011:73), penelitian desktiptif kualitatif ditujukan guna mendeskripsikan serta menggambarkan kejadian yang terjadi, baik itu berbentuk alamiah ataupun buatan manusia manusia, pada hal ini sangat memperhatikan karakteristik, kualitas, keterkaitan terhadap kegiatan. Selain itu, penelitian deskriptif ini tidak memberikan tindakan, kepalsuan atau perubahan terhadap variabel yang sedang diteliti, tetapi memberikan gambaran mengenai suatu keadaan yang benar benar terjadi. Tindakan yang bisa diberikan hanyalah dari penelitian yang benar terjadi, yang dilakukan melalui observasi, wawancara, serta dokumentasi.

Pertimbangan yang menjadi alasan bagi penulis untuk bisa yakin untuk memilih menggunakan metode deskriptif dikarenakan dengan memilih metode ini penulis bisa mendeskripsikan objek penelitian serta mengamati secara lebih spesifik. Sehingga ilmu yang sudah didapatkan pada saat tertentu bisa diterangkan dengan lebih mendetail serta bisa diberikan solusi guna memecahkan masalah yang ada.

Penelitian ini dilakukan di Kajeksan RT 04 RW 01 Kota Kudus, yaitu dengan subjek penelitian dua sampai tiga orang tua dari siswa kelas I SDN 01 Kajeksan Kudus. Teknik dalam mendapatkan data dalam penelitian ini yaitu dengan menggunakan teknik observasi disekolah terhadap guru dan dua sampai tiga orangtua siswa kelas 1 SDN 01 Kajeksan Kudus dan teknik wawancara yakni memberikan pertanyaan terhadap guru beserta orang tua siswa kelas 1 SDN 01 Kajeksan Kudus.

\section{HASIL PENELITIAN DAN PEMBAHASAN}

\section{Hakikat Belajar}

Belajar yaitu kegiatan yang dilakukan seorang individu guna menginginkan perubahan pada kemampuan dirinya, melalui belajar anak yang belum mampu untuk berbuat sesuatu, akan menjadi bisa melakukan hal tersebut, atau dengan kata lain anak yang belum terampil bisa menjadi terampil.

\section{Pembelajaran}

Pembelajaran yaitu proses yang bisa dilakukan oleh individu guna mendapatkan sebuah perubahan pada perilaku yang baru dengan menyeluruh, hal ini didapatkan dari adanya hasil dari pengalaman seorang individu itu di dalam berinteraksi terhadap lingkungannya (Surya,2004)

\section{Pembelajaran daring}

Pembelajaran daring sendiri memfokuskan terhadap belajar menggunakan bantuan internet, hal ini juga sudah diungkapkan oleh Koran (2002) jika e-learning yaitu kegiatan pengajaran serta pembelajaran dengan memanfaatkan alat elektronik baik itu LAN ataupun WAN, serta internet guna memberikan materi pembelajaran, diskusi, bimbingan ataupun penilaian. Begitu pun Rosembang (2001) berpendapat bahwa pembelajaran daring lebih mengutamkan pemanfaatan teknologi internet sebagai solusi yang dapat digunakan dalam meningkatkan pengetahuan, kreatifitas serta keterampilan. 


\section{Pengaruh Negatif dan Positif Pembelajaran Daring. Pengaruh Positif pembelajaran Daring}

a. Bisa mencegah penularan virus covid19

b. Membuat siswa bisa lebih mandiri serta bertanggung jawab

c. Menjadikan guru jadi lebih kreatif di dalam mempersiapkan media pembelajaran serta kuis dan juga multimedia yang dapat mendukung kegiatan pembelajaran

d. Membuat guru jadi lebih terampil di dalam melaksanakan kegiatan pembelajaran secara online

e. Guru jadi lebih bisa memanfaatkan aplikasi elearning

f. Membuat waktu pembelajaran menjadi efektif

\section{Pengaruh Negatif Pembelajaran Daring}

a. Komunikasi jadi berkurang antara guru dengan siswa

b. Pembelajaran menjadi susah untuk di control

c. Adanya Kesulitan dalam melakukan evaluasi pada anak

d. Pembelajaran hanya terfokus pada aspek kognitif saja, sehingga aspek afektif serta psikomotorik menjadi aspek yang tidak diutamakan.

e. Persepsi buruk dari orang tua siswa kepada guru.

f. Biaya yang dikeluarkan orang tua semakin besar untuk pembelajaran online

\section{Dampak Proses Belajar dari Rumah bagi Orang Tua}

Dampak BDR bagi orang tua antara lain:

a. Adanya kesempatan untuk orang tua dekat terhadap anak

b. Orang tua bisa mendampingi anak saat belajar serta dapat memahami kesulitan yang dialami anak serta guru di sekolah

c. Anak menjadi terlalu senang untuk bermain gadget 'games'

d. Penggunaan gadget, pulsa serta istrik menjadi tinggi.

\section{Landasan Pembelajaran Daring}

Covid-19 atau yang lebih sering disebut Virus Corona pertama kali muncul di Tiongkok pada bulan Desember tahun 2019, virus itu mulai menyebar di berbagai negara pada masa awal 2020 dan pertama masuk ke Indonesia pada bulan Maret 2020. Pada tanggal 11 Maret tahun 2020 WHO mengumumkan bahwa wabah tersebut ditetapkan sebagai pandemi. Sekarang ini, secara international yang telah meninggal sudah mencapai 316.860 orang serta di Indonesia sendiri telah mencapai pada angka 1.192 orang (data per 18 2020) (Syahruddin, 2020:1). Untuk mengurangi penyebaran virus corona, langkah penting yang sudah diambil oleh pemerintah antara lain mengadakan aturan untuk bekerja dari rumah, serta belajar dan beribadah dirumah. Terdapat beberapa kendala yang menjadi hambatan pada saat proses kegiatan pembelajaran daring, seperti dari masalah teknis hingga sampai pada saat proses pembelajaran seperti gangguan jaringan, mengoperasikan aplikasi google meet, google classroom, serta sebagainya (Syahrudin \& Mutiani, 2020:3).

\section{Standar Materi Pembelajaran Daring}

Untuk memenuhi isi dari pembelajaran daring supaya memenuhi keseluruhan isi dari kurikulum, maka standar isi materi tersebut harus mengacu pada standar isi terhadap satuan pendidikan meliputi:

a. Kerangka dasar dan struktur kurikulum

Materi yang ada di dalam sistem 
pembelajaran daring harus disiapkan secara sistematis serta harus terstruktur mengikuti kerangka dasar serta struktur kurikulum.

b. Beban belajar

Materi yang ada pada sistem pembelajaran daring tersebut harus memuat informasi beban belajar yang harus didapat oleh peserta didik.

c. Kurikulum tingkat satuan pendidikan Materi yang terdapat pada sistem pembelajaran daring harus berisi kurikulum yang harus terdiri dari beberapa kelompok mata kuliah/pelajaran, tiap kelompok mata kuliah/pelajaran harus terdiri dari beberapa mata kuliah/ pelajaran yang sudah sesuai terhadap standar isi di setiap satuan pendidikan.

d. Kalender pendidikan

Materi di dalam pembelajaran daring harus dapat dideliverikan menurut kalender pendidikan.

\section{Pengertian Persiapan}

Slameto (2003) menyimpulkan bahwa persiapan sebagai keseluruhan dari kondisi seseorang yang membuatnya siap memberikan respons serta jawaban serta cara tertentu terhadap sebuah situasi.

Dalyono (2005) berpendapat bahwa kesiapan adalah suatu kemampuan fisik dan mental yang sudah cukup baik. Kesiapan fisik mempunyai arti bahwa sudah memiliki tenaga yang baik serta kesehatan yang cukup baik. Kesiapan mental artinya memiliki minat serta motivasi yang cukup guna dapat melaksanakan sebuah kegiatan.

Dari beberapa pendapat diatas bisa diambil kesimpulan bahwa kesiapan yaitu kemampuan di dalam melaksanakan kegiatan pada respons serta situasi yang baru.

\section{Pengertian Orang Tua}

Pengertian orang tua di dalam arti umum yaitu orang tua (dewasa) yang bisa bertanggung jawab pada kelangsungan hidup anaknya yang termasuk dalam pengertian ini yaitu ayah serta ibu, kakek,nenek, paman, bibi, kakak, serta wali. pengertian orang tua dalam arti khusus sendiri yaitu orang tua hanya ayah serta ibu saja.

Dari teori diatas, bisa diambil kesimpulan jika yang dimaksud dengan orang tua yaitu ayah serta ibu yang berada di dalam sebuah keluarga.

\section{Peran Orang Tua Selama Pembelajaran Daring}

Dorongan orang tua serta dukungan untuk aktivitas belajar di rumah digabungkan terhadap keterlibatan guru pada saat memberikan materi belajar sangat berperan penting bagi keberlangsungan pendidikan anak. Sudah banyak sumber yang membuktikan bahwa membangun kemitraan yang efektif dari orangtua, keluarga, serta sekolah guna mendukung pembelajaran anak akan mendatangkan dampak yang baik pada hasil belajar. Orangtua yaitu pendidik pertama serta berkelanjutan terhadap anak-anak mereka. Penelitian juga sudah mengungkapkan jika kualitas guru, termasuk standar serta pelatihan di dalam keterlibatan orangtua, sangat penting guna membantu keterlibatan dari orang tua agar lebih efektif. Dianggap luas, keterlibatan orangtua sendiri terdiri atas beberapa kemitraan antara lain keluarga, sekolah serta masyarakat, memaksimalkan kesadaran orangtua mengenai manfaat dalam keterlibatan di dalam pendidikan anak-anak belajar dirumah.

Dampak yang dihadapi oleh orang tua di dalam sistem pembelajaran jarak jauh dengan sistem sekolah online memang 
cukup beragam. Orang tua memang harus menambah beban pengeluaran finansial guna memberikan fasilitas yang cukup memadai untuk anak agar bisa mengikuti pembelajaran dengan daring, tentunya hal ini mengharuskan orang tua untuk menyiapkan setidaknya kuota internet yang mencukupi atau bisa dengan berlangganan jaringan WiFi yang tidak murah hal ini semata-mata agar proses belajar secara online yang sedang dilaksanakan oleh anak bisa berlangsung dengan lancar. Dampak berikutnya yang harus dilalui oleh orang tua di dalam kegiatan pembelajaran jarak jauh dengan sistem online ini adalah terkait dengan waktu. Orang tua harus wajib meluangkan waktu yang cukup ekstra agar bisa mendampingi anak di dalam melaksanakan sekolah online. Karena anak kemungkinan masih belum tentu dapat untuk mengakses serta menyerap materi dan tugas-tugas dari belajar online ini, sehingga orang tua harus turut hadir untuk mengawasi serta memberikan perhatian ekstra kepada anak baik itu di saat sebelum pembelajaran dimulai, saat pembelajaran berlangsung, ataupun pada saat pembelajaran sudah selesai. Agar isi serta materi dari sekolah online ini tidak menjadi sia-sia. Hal ini tentu saja sangat mempengaruhi terhadap waktu yang dipunyai oleh orangtua guna melakukan kegiatan pribadinya misalnya bekerja, kegiatan rumah tangga serta yang lain sebagainya. Desain dari pembelajaran jarak jauh dengan metode sekolah online juga harus memaksa orang tua agar bisa menggunakan teknologi. Karena orang tua yang akan mengajarkan teknologi itu kepada anaknya. Orang tua juga harus kreatif serta inovatif di dalam mendampingi kegiatan sekolah online serta memberikan arahan dan tuntunan terhadap anak agar bisa memanfaatkan akses teknologi modern di dalam kegiatan pembelajaran yang kedepannya bisa akan mmaksimalkan kualitas anak itu sendiri (Prasojo \& Riyanto, 2011). Orangtua yang memiliki kendala terhadap kegiatan kerjanya ditambah lagi tuntutan untuk dilakukannya pendampingan belajar anak di rumah, sebagian orang tua mungkin ada yang melampiaskan hal itu kepada guru. Tetapi, ada juga orang tua yang sadar akan tugas yang selama ini dijalani para guru di sekolah. Mereka menjadi sadar betapa beratnya mendampingi belajar satu atau dua orang anak kandungnya sendiri dirumah, sementara guru harus memberikan waktu perhatian serta bimbingan terhadap dua puluh anak di sekolah dengan penuh kesabaran serta telaten. Sehingga kegiatan pembelajaran jarak jauh dengan metode sekolah online ini pada akhirnya juga membawa dampak terhadap orangtua yang akhirnya mengapresiasi kegigihan guru selama ini mendampingi belajar anaknya di sekolah.

Ada empat peran orang tua di dalam Pembelajaran Jarak Jauh (PJJ) atau pembelajaran daring menurut (Cahyati, 2020: 155) yaitu:

a. Para Orang tua bisa menjadi pengganti dari guru selama adanya pembelajaran di rumah

b. Orang tua berperan sebagai fasilitator, dengan kata lain orang tua menjadi sarana serta pra sarana bagi anaknya dalam melakukan pembelajaran jarak jauh.

c. Orang tua sebagai motivator, yaitu orang tua harus bisa memberikan semangat dan dukungan untuk anaknya di dalam melakukan pembelajaran, sehingga anak bisa bersemangat dalam mengikuti pembelajaran, serta bisa memperoleh prestasi yang memuaskan.

d. Orang tua berperan sebagai pengaruh atau director, Orang tua memiliki 
peran agar selalu membimbing anaknya untuk bisa mencapai keberhasilan di masa mendatang. Orang tua juga harus berperan aktif guna mengarahkan anak sesuai dengan bakat serta minat yang anak anak miliki. anak mempunyai bakat yang berbeda karena anak berhak untuk mendapat impiannya.

\section{Aspek Mendidik Anak Belajar di Rumah}

Liem Hwei (Kartono.1985:91) berpendapat bahwa terdapat 5 aspek yang harus dilakukan orang tua dalam mendidik anak dirumah

a. Dapat menyiapkan fasilitas guna menunjang Belajar anak

b. Mengawasi jalannya aktivitas pada pembelajaran anak selama dirumah

c. Mampu mengatur waktu yang dibutuhkan belajar anak di rumah

d. Mengawasi kesulitan dialami oleh anak selama belajar dirumah

e. Dapat menolong anak guna memberi solusi dalam mengatasi kesulitan dalam belajar di rumah.

\section{Solusi Yang Bisa Dilakukan Oleh Orang Tua Bagi Pendidikan di Era Pandemi}

Orang tua sebagai pendidik pertama di rumah tangga wajib memenuhi fungsinya. Meskipun demikian tetap saja bantuan dari guru di sekolah masih perlu perlu butuhkan, yaitu dengan hadir door to door ke semua peserta didik. Ini harus membuka cakrawala serta tanggung jawab orang tua jika pendidikan anaknya harus dikembalikan pada effort orang tua di dalam membentuk mental, sikap serta pengetahuan anaknya.

Orang tua juga harus menyadari serta mengetahui bagaimana cara membimbing anak mereka di dalam kegiatan belajar, karena pada dasarnya rumah yaitu tempat pertama dan utama untuk mendidik anak. Oleh karena itu dengan dilakukannya pembelajaran online di rumah ini maka waktu anak menjadi lebih banyak di rumah serta mereka perlu bimbingan dari para orang tuanya. Fungsi rumah pada saat ini menjadi bertambah yaitu juga sebagai sekolah, orang tua harus banyak belajar untuk bagaimana mendidik serta memberikan ilmu pengetahuan terhadap anak, sebab fungsi guru atau sekolah hanya sebagai fasilitator.

Masa pandemi seperti ini sebaiknya diberikan tanggung jawab penuh terhadap orang tua guna mendidik anaknya dalam konteks pembelajaran yang tidak terlalu terikat dengan kurikulum serta materi yang ada di dalam buku ajar.

Peranan orang tua juga bermanfaat di dalam memperhatikan proses belajar anaknya, jangan sampai anaknya hanya bermain ponsel saja, dengan alasan mencari tugas, akan tetapi malah mencari hal yang tidak seharusnya, serta belajarnya jadi tertunda.

\section{Belajar di Rumah Menurut Persepsi Orang Tua Siswa \\ Dari hasil wawancara serta} observasi yang sudah dilakukan penulis terhadap kesiapan para orang tua kelas 1 SDN Kajeksan Kudus penulis mendapat informasi mengenai pendapat orang tua siswa mengenai belajar di rumah yakni dari salah satu narasumber yakni ibu (anik) bahwa dengan adanya belajar dirumah ini orang tua jadi merasakan apa yang sudah dirasakan oleh guru, ternyata sangat tidak mudah untuk mendampingi belajar anak dengan berbagai permasalahnnya, terutama soal kesabaran yang perlu untuk lebih dilatih lagi. Dan juga menurut narasumber dengan adanya belajar di rumah ini orang tua bisa mengawasi siswa untuk belajar. 
Kendala yang di Hadapi Selama Mendampingi Anak Belajar di Rumah

Dari hasil wawancara serta hasil observasi yang sudah dilakukan oleh penulis, didapatkan beberapa informasi jika hal yang menjadi kendala di dalam mendampingi anak dirumah antara lain, susah nya untuk memahami materi atau tugas yang diberikan oleh guru karena guru tidak memberikan penjelasan yang jelas akan tugas tersebut, hal tersebut membuat para orang tua kebingungan. Serta pekerjaan orang tua di rumah juga menjadi kendala tersendiri para orang tua dalam mendidik atau membimbing anak dirumah. Seperti hasil observasi yang didapatkan dari salah orang tua siswa yaitu ibu (nur) yang waktu dalam membimbing serta mendampingi anak cukup sedikit karena pekerjaan dia yang bekerja di pabrik yang mengharuskan untuk pulang setiap sore dan hanya punya waktu malam hari untuk membimbing anaknya atau diwaktu pekerjaan nya libur.

\section{Materi yang biasa diberikan oleh Guru Kelas 1 SDN 01 Kajeksan Kudus}

Dari hasil wawancara yang dilakukan oleh peneliti terhadap ibu (fidah) jika materi biasanya diberikan oleh guru di SDN Kajeksan Kudus dikirimkan lewat group whatsApp. Dan dari hasil observasi yang dilakukan oleh peneliti bahwa para orang tua cenderung ketinggalan dalam memeriksa atau mengetahui jika ada tugas yang dikirimkan dari guru di whatsApp group jadi jika ada sesama orang tua yang baru bercerita baru orang tua tersebut mengetahui jika sudah ada tugas yang dikirim.

\section{KESIMPULAN}

Di dalam pembelajaran daring masih banyak kendala yang dihadapi oleh orang tua di dalam mempersiapkan pembelajaran yang terbaik untuk anaknya antara lain, permasalahan pada materi yang kadang orang tua masih merasa bingung ketika akan menerangkan ke anak karena guru hanya memberi tugas tanpa menjelaskan secara detail tugas itu bagaimana, dan juga masalah waktu yang kurang banyak di dalam mendampingi anak dalam belajar di karenakan masalah pekerjaan dari orang tua tersebut yang mengakibatkan pembelajaran di rumah bagi anak nya kurang maksimal.

\section{DAFTAR PUSTAKA}

Afrillia dkk. 2020. Minda Guru Dan Keberlangsungan Pembelajaran Di masa Pandemi Covid -19. Aceh, Syiah Kuala University Pers.

Bilfaqih dan Qomarudin M. Nur. 2012. Esensi Penyusunan Materi Pembelajaran Daring. Yogyakarta. CV Budi Utama.

Dian Ni Putu. 2020. Bali Vs Covid-19. Bali, Nilacakra.

Handayani Tri. 2020. "Peran Orang Tua Dalam Membimbing Anak Pada Pembelajaran Daring Di Desa Ngrapah Kecamatan Banyuwangi Tahun Pelajaran 2019/2020”. Salatiga : IAIN Salatiga. http://erepository.perpus.iainsalatiga .ac.id/9989/1/skripsi\%20pdf.pdf.dia kses tanggal 17 Desember 2020 Pukul 11.39 WIB.

Kusumawati Naniek \& Srimaruti Endang. 2019. Strategi Belajar Mengajar Di sekolah Dasar. Solo. CV Ae Media Grafika.

Lefudin. 2012. Belajar dan Pembelajaran dilangkapi dengan model pembelajaran strategi pembelajaran pendekatan pembelajaran dan metode pembelajaran. Yogyakarta. CV. Budi Utama. 
Luthfiyah Siti Zakiyatul. 2020. Persepsi Orang Tua Mengenai Pembelajaran Online Di Rumah Selama Pandemi Covid-19, ISSN 2655-8491, Vol. No 2.http://erepository.perpus.iainsalati ga.ac.id/1315/1/SKRIPSI\%20FIX.p df. Diakses pada tanggal 17 Desember 2020 Pukul 11.21 WIB.

Mutaqinah Rina \& Hidayatullah. 2020. Implementasi Pembelajaran Daring (Program BDR) Selama Pandemi Covid-19 di Provinsi Jawa Barat, Jurnal Petik, p-ISSN:2640-7363 eISSN: 2614-6606, Volume 6, Nomor 2.https://journal.institutpendiidkan.a c.id/index.php/petik/article/view/86 9. Diakses tanggal 18 Desember 2020 Pukul 13.24

Nurkhalima Siti. 2020. " Peran Orang Tua Dalam PembelajaranDaring Di Mi Darul Ulum Pedurungan Kota Semarang Tahun Pelajaran 2020/2021". Salatiga : IAIN Salatiga.http://erepository.perpus.iai nsalatiga.ac.id/9839/1/Skripsi\%20Si ti\%20Nur\%20khalimah\%20230401 60013.pdf

Prasetyo Fajar Ahmad Dwi. 2020. Pendampingan Orang Tua Dalam Proses Belajar Anak (Studi Deskriptif Tentang Tingkat Optimalisasi Pendampingan Orang Tua Dalam Proses Belajar Anak Menurut Persepsi Siswa Kelas X Smk N1 Nanggulan Tahun Ajaran 2017/2018).(Yogyakarta: Univesitas Sanata Dharma.

http://repository.usd.ac.id/18145/1/1 41114056.pdf. Diaksess tanggal 18 Desember 2020 Pukul 22.58 WIB.

Slameto. 2003. Belajar dan Faktor-faktor yang mempengaruhinya. Jakarta: Rineka Cipta.

Tahir Thamrin dkk. 2020. Perubahan Paradigma Pendidikan Dan Ekonomi Di masa Pandemi Covid 19: Peluang Tantangan Dan Strategi. Bandung, CV Media Sains Indonesia.
Tim Dosen PAI. 2016. Bunga Rampai Penelitian Dalam Pendidikan Agama Islam. Yogyakarta. Deepublish.

Whardhani Tsaniya Zahra Yuthika \& Krisnani Hetty. 2020. “Optimalisasi Peran Pengawasan Orang Tua Dalam Pelaksanaan Sekolah Online Di masa Pandemi Covid-19". Prosiding Penelitian\&Pengabdian Kepada Masyarakat. e ISSN: 25811126 p ISSN: 2442-448X. Vol. 7. No: 1.

http://Jurnal.Unpadac.id/prosding/ar ticle/view/28256. diakses pada 17 Desember 2020. Pukul 11,30 WIB.

Wijaya David. 2019. Manajemen Pendidikan Inklusif Sekolah Dasar. Jakarta, Kencana. 